\title{
Distribution of Se in Soybean Samples with Different Se Concentration
}

\author{
Zijian Wang,* Shenmeng Xie, and An Peng
}

\author{
State Key Laboratory of Aquatic Environmental Chemistry, P.O. Box 2871, Beijing 100085, China
}

\begin{abstract}
Soybean samples from low-Se, Se-adequate and excessive Se regions were collected for determination of the distribution of Se in plant components. Chemical extraction indicated that most of Se was found in proteins, chitin, and polysaccharides. Based on chemical extraction and SDS-PAGE separation, the affinities of whey protein and, to a less extent, the affinity of the 11S globulin polypeptides were stronger for Se than that of $7 \mathrm{~S}$ globulin polypeptides. The binding of Se to 7S and 11S under excessive Se environment was mostly nonspecific and could easily be detached from proteins during SDS-PAGE separation.
\end{abstract}

\section{Keywords: Selenium; soybean; distribution}

\section{INTRODUCTION}

Both Se deficiency or Se intoxication in China has been reported (EGAS, 1990; Yang, 1993). Se deficiency was found to be associated with Kashin-Beck disease, Keshan disease, white muscle disease in animals, and endemic liver cancer (Gu, 1989). Se intoxication was reported in Enshi county where the habitants suffered from a number of symptoms (Mao et al., 1990). The occurrences of Se in soil, potable water, crops, human hair, and blood, including their putative casual associations to Se deficient diseases, have been extensively studied (Peng et al., 1991; Wang et al., 1991a). Chemical forms of this element in soil and potable water were also determined in the Chinese low-Se belt (Wang, 1993).

Research has revealed that the chemical forms of Se influences the bioavailability when used as a preventive measure for Kashin-Beck disease (Hou, 1989). The chemical transformations in metabolic processes depend on the Se forms in the diet (Beilstein and Whanger, 1986). The major form of Se in rice and wheat from high-Se regions was shown to be selenomethionine (Beilstein et al., 1991) and in proteins from soybeans labeled with ${ }^{75}$ Se (Sathe et al., 1992). A comparative study on Se distribution in soybean components, protein fractions, and molecular weight components is reported in this paper.

\section{EXPERIMENTAL PROCEDURES}

Sample Collection. Samples were collected from Enshi county (seleniferous region) where Se intoxication of human beings had been reported, from Beijing city where the Se level is in an adequate range, and from Tianshui city, Ganshu Province and Yanbian area, J ilin Province, both areas where Se deficiency and high incidence of Kashin-Beck disease were prominent.

Selenium Determination. Selenium determinations were performed by the method developed in our laboratory (Wang and Sun, 1988). Soybean seeds, fractions from extraction steps and sliced gel bands from SDS-PAGE were digested in a mixture of nitric acid and perchloric acid (5:2 (v/v), GR; Shanghai Chem. Co.) at $210^{\circ} \mathrm{C}$. After digestion, the solution was treated with $4 \mathrm{~N} \mathrm{HCl}$ for $10 \mathrm{~min}$ at $170^{\circ} \mathrm{C}$ and cooled to room temperature, and the $\mathrm{pH}$ was adjusted to 1.5 with ammonium hydroxide (1:1 diluted with distilled water, GR; Beijing Chem. Co.). The 2,4-diaminonaphthalene (Sigma AG) derivative of selenite was extracted into the cyd ohexane phase.
After centrifugation at $4000 \mathrm{~g}$ a portion $(20-100 \mu \mathrm{L})$ of the organic phase was injected into normal phase HPLC (Waters 201 HPLC W/510 with Shimadzu RF-535 fluorescence detector and $\mu$-porosil $\mathrm{C}_{18}-\mathrm{NH}_{2}$ column; mobile phase, $\mathrm{THF}: \mathrm{H}_{2} \mathrm{O}=9: 1$, $(v / v))$, and the naphthoselenodiazol was determined by retention time and cochromatography with standards. The peak height was used to calculate the selenium content. The method was calibrated with selenite as the standard in the range of $0-0.6 \mu \mathrm{g} / \mathrm{L}$ and confirmed with an external certified reference material (rice flour, J apan Environmental Agency, NIES 10).

Chemical Extraction. Two independent extraction procedures were used for fractionating the components of soybean samples. In the first procedure, soybean flour was treated with cold $10 \%$ trichloroacetic acid (TCA) with constant magnetic stirring. The supernatant was transferred to a flask and the volume adjusted to $50 \mathrm{~mL}$ for the determination of Se. The residue from the above step was extracted by methanol for 5 $\mathrm{min}$, by chloroform at $20^{\circ} \mathrm{C}$ for $20 \mathrm{~min}$, and by a mixture of methanol/chloroform (1:2 (v/v)) under reflux for $20 \mathrm{~min}$ to remove lipids and lipoproteins. The organic phases were combined and several drops of concentrated hydrochloric acid added and evaporated to near dry under $70^{\circ} \mathrm{C}$, and this was used for Se determination. The residue from organic solvent extraction was dried at ambient temperature and refluxed in $30 \mathrm{~mL}$ of $5 \%$ TCA at $90{ }^{\circ} \mathrm{C}$ for 30 min to extract nucleic acids. Solid residue from the last extraction was dried and weighed, and a portion was taken for determining Se. This method was based on that proposed by Piepponen et al. (1984) which separates the soybean components into low molecular weight compounds, lipids and lipoproteins, nucleic acids, and a residue that remains in the solid after extraction. According to Piepponen et al. (1984), the residue contains mainly polysaccharides, chitin, and proteins which are insoluble in the solvents used.

The second procedure used was that of Thanh and Shibasaki (1976) with minor changes. Dried soybean powder was defatted with cold acetone at $4{ }^{\circ} \mathrm{C}(1: 2.5(\mathrm{w} / \mathrm{v}), \mathrm{GR}$, Beijing Chem. Co.) and air-dried in a clean room. The defatted sample was extracted by a mixture of $20 \mathrm{mM}$ Tris, $0.1 \% \beta$-mercaptoethanol, and $1 \mathrm{mM} \mathrm{NaN}_{3}$ (pH 8.5) to obtain water soluble fractions (meal:buffer, 1:10). The supernatant was adjusted to $\mathrm{pH} 6.5$ to precipitate a $11 \mathrm{~S}$ globulin fraction and to $\mathrm{pH} 4.5$ to precipitate a 75 protein fraction. Ammonium sulfate $(45 \%$ by weight) was added to precipitate whey proteins from the supernatant. The precipitate from each step and the supernatant from the last step were freeze-dried. The Se content of each fraction was determined. This method separates the soybean components intolipids, water soluble protein fractions (11S, 7S, and whey, respectively), a solid residue left after soluble protein extraction, and small molecular weight compounds which remain in liquid phase after precipitation of the 
Table 1. Major Element Content in Soybean Samplesa

\begin{tabular}{ccccc}
\hline & \multicolumn{3}{c}{ content for given sampling site } \\
\cline { 2 - 5 } element & $\begin{array}{c}\text { Enshi } \\
\text { county }\end{array}$ & $\begin{array}{c}\text { Beijing } \\
\text { city }\end{array}$ & $\begin{array}{c}\text { Tianshui } \\
\text { region }\end{array}$ & $\begin{array}{c}\text { Yanbian } \\
\text { region }\end{array}$ \\
\hline $\mathrm{Se}$ & $2.3 \pm 0.4$ & $0.26 \pm 0.01$ & $0.10 \pm 0.02$ & $0.13 \pm 0.02$ \\
$\mathrm{Fe}$ & 75.5 & 74.7 & 72.8 & 81.8 \\
$\mathrm{Mn}$ & 33.8 & 33.2 & 35.9 & 35.0 \\
$\mathrm{Cab}$ & 0.4 & 0.2 & 0.2 & 0.2 \\
$\mathrm{~Pb}^{\mathrm{b}}$ & 0.7 & 0.7 & 0.6 & 0.6 \\
$\mathrm{Mg}$ & 0.3 & 0.3 & 0.2 & 0.2 \\
$\mathrm{Zn}$ & 57.6 & 57.8 & 57.8 & 44.8 \\
$\mathrm{Cu}$ & 7.2 & 7.7 & 7.2 & 6.1 \\
$\mathrm{Ni}$ & 1.1 & 1.0 & 1.0 & 1.0 \\
$\mathrm{~Pb}$ & 1.0 & 1.0 & 1.0 & 1.0
\end{tabular}

a For Se, the sample number is $\mathrm{N}=3$ and determined by the DAN fluorescence method. For other elements, sample number is $\mathrm{N}=1$ and determined by $\mathrm{X}$-ray fluorescence spectroscopy. ${ }^{\mathrm{b}} \mathrm{U}$ nit in percentage, other are milligrams per kilogram.

whey proteins. The solid residue contains mainly insoluble lipoproteins, chitin, and polysaccharides when compared with the extraction procedure proposed by Piepponen et al. (1984).

SDS-PAGE Separation. A $0.3 \mathrm{~g}$ sample of soybean powder was homogenized in a $3 \mathrm{~mL}$ mixture of $62.5 \mathrm{mM}$ Tris $/ \mathrm{HCl}, 4 \%$ SDS, $5 \% \beta$-mercaptoethanol, $10 \%$ sucrose, and $0.002 \%$ bromophenol blue to obtain the test solution. The test solution was centrifuged at $5000 \mathrm{~g}$ and boiled for $3 \mathrm{~min}$ before use. SDSPAGE was used as described by Laemmli (1970). Proteins in test solution were concentrated in 5\% acryl amide gel under a constant current of $10 \mu \mathrm{A}$ and electrophoresed in $12.5 \%$ gel for $30 \mathrm{~h}$ with a constant current of $20 \mu \mathrm{A}$. In a $200 \times 180 \times$ $3 \mathrm{~mm}$ cell for a total of 12 lanes, 6 lanes were added with blanks and others were added with test sol ution. The solution for homogenizing the samples was used for blanks. At end of the electrophoresis, the gels were stained with Coomassie Brilliant Blue R for $12 \mathrm{~h}$ (with $7 \%$ acetic acid and $30 \%$ methanol) and destained with 7\% acetic acid for 3 days. Visualized protein bands and the parallel blanks of the same width were sliced separately and the sliced bands used for Se determination. After deducting the parallel blank, the Se content in each band was calculated on the basis of three duplicates. The bands with mean Se content exceeding 2 standard deviations were considered to be Se-containing ones.

Elements and Amino Acids Determination. The elemental composition of the samples was determined by mode 3070E X-ray fluorescence spectroscopy (J apan Physics Co.). Sample preparation and instrumental conditions were the same as those used in calibrating the national standard reference material of mussel (C86-701, Wang et al., 1991a). For amino acid analysis, $30 \mathrm{mg}$ of soybean powder was hydrolyzed in airtight ampules with $10 \mathrm{~mL}$ of $6 \mathrm{~N} \mathrm{HCl}$ at 110 ${ }^{\circ} \mathrm{C}$ for $22 \mathrm{~h}$. The hydrolysate was adjusted to $50 \mathrm{~mL}$ by distilled water, and $1 \mathrm{~mL}$ was dried under vacuum. The dried hydrolysate was dissolved in $1 \mathrm{~mL}$ of $0.02 \mathrm{M} \mathrm{HCl}$ and filtered through a $0.45-\mu \mathrm{m}$ filter. The amino acids were determined with an Itachi Model 835 amino acid analyzer using ninhydrin as the color reagent. Total raw protein content was determined with the Model KN-01 Kjeldahl's nitrogen analyzer (Mitsubishi Chem. Industries, Inc., J apan) using the national standard method (GB-2905, National Standard Bureau).

\section{RESULTS AND DISCUSSION}

Chemical Composition of the Samples. The elemental composition of the samples is given in Table 1. Only slight differences in the elemental content were observed among samples from different sampling re gions except for Se. As expected the Se contents in samples collected from different regions of China varied widely.

Table 2 gives the amino acid composition and total protein content of the samples. The total protein content on the dry weight basis ranged from 39.5 to $46.4 \%$. Significant differences were found between
Table 2. Total Protein and Amino Acid Contents in Soybean Samples ${ }^{a}$

\begin{tabular}{lcccc}
\hline & \multicolumn{4}{c}{ content for given sampling site } \\
\cline { 2 - 5 } $\begin{array}{c}\text { protein or } \\
\text { amino acid }\end{array}$ & $\begin{array}{c}\text { Enshi } \\
\text { county }\end{array}$ & $\begin{array}{c}\text { Beijing } \\
\text { city }\end{array}$ & $\begin{array}{c}\text { Tianshui } \\
\text { region }\end{array}$ & $\begin{array}{c}\text { Yanbian } \\
\text { region }\end{array}$ \\
\hline protein & $46.44^{\mathrm{b}}$ & 40.72 & 40.72 & 43.50 \\
proline & $2.34^{\mathrm{b}}$ & 1.82 & 1.86 & 1.96 \\
cysteine & $0.24^{\mathrm{b}}$ & 0.14 & 0.11 & 0.12 \\
isoleucine & $1.84^{\mathrm{b}}$ & 1.54 & 1.60 & 1.67 \\
aspartic acid & $4.82^{\mathrm{b}}$ & 3.78 & 3.80 & 3.92 \\
serine & $2.31^{\mathrm{b}}$ & 1.72 & 1.76 & 1.81 \\
glutamic acid & $8.58^{\mathrm{b}}$ & 7.02 & 7.34 & 7.82 \\
phenylalanine & $2.39^{\mathrm{b}}$ & 1.88 & 1.92 & 1.98 \\
threonine & $1.72^{\mathrm{b}}$ & 1.43 & 1.48 & 1.46 \\
glycine & 1.86 & 1.56 & 1.74 & 1.47 \\
alanine & $1.88^{\mathrm{b}}$ & 1.56 & 1.64 & 1.66 \\
valine & $2.00^{\mathrm{b}}$ & 1.68 & 1.76 & 1.84 \\
methionine & 0.50 & 0.48 & 0.45 & 0.51 \\
lysine & 2.70 & 2.30 & 2.50 & 2.58 \\
leucine & $3.32^{\mathrm{b}}$ & 2.78 & 2.95 & 3.02 \\
tyrosine & 1.32 & 1.34 & 1.42 & 1.44 \\
hisditine & 1.12 & 1.02 & 1.04 & 1.10 \\
arginine & 3.50 & 2.96 & 3.08 & 3.35 \\
ammonia & $1.16^{\mathrm{b}}$ & 0.96 & 0.90 & 1.00
\end{tabular}

a Data expressed as percent of dry mass. Determination was performed in a single run. ${ }^{b}$ Data exceeds the average of the other three samples by 2 standard deviations.

Table 3. Percentage Distribution of Se in Soybean Components (\%) ${ }^{a}$

\begin{tabular}{lcccc}
\hline & \multicolumn{4}{c}{ content for given sampling site } \\
\cline { 2 - 5 } \multicolumn{1}{c}{ component } & $\begin{array}{c}\text { Enshi } \\
\text { county }\end{array}$ & $\begin{array}{c}\text { Beijing } \\
\text { city }\end{array}$ & $\begin{array}{c}\text { Tianshui } \\
\text { region }\end{array}$ & $\begin{array}{c}\text { Yanbian } \\
\text { region }\end{array}$ \\
\hline low mol wt & $6.3 \pm 0.7$ & $4.5 \pm 0.3$ & $10.6 \pm 3.3$ & $9.9 \pm 2.2$ \\
$\quad \begin{array}{c}\text { compounds } \\
\text { lipids and }\end{array}$ & $6.8 \pm 0.7$ & $8.6 \pm 2.4$ & $9.8 \pm 0.3$ & $6.6 \pm 1.5$ \\
$\quad$ lipoproteins & & & & \\
$\begin{array}{l}\text { nucleic acids } \\
\text { solid residueb }\end{array}$ & $5.3 \pm 0.3$ & $5.7 \pm 1.1$ & $2.4 \pm 1.7$ & $8.3 \pm 3.8$ \\
recovery (\%) & 70 & $91.3 \pm 1.0$ & $61.2 \pm 5.2$ & $69.3 \pm 1.1$ \\
& & 90 & 84 & 94
\end{tabular}

a Extraction procedure followed that proposed by Piepponen et al. (1984); standard deviation was calculated from three duplicates $(\mathrm{N}=3) .{ }^{\mathrm{b}}$ This fraction was assumed containing mainly chitin, proteins, and polysaccharides.

samples of Enshi county and others for total protein contents and for some of the amino acids. The reason for the influence of Se on protein synthesis is not clear, but correlation between environmental Se and protein contents have been reported (Yin et al., 1986). Experiments have shown that addition of sel enite to soil can increase the protein content in wheat (Cui and Yin, 1993). When cultured in high-Se medium, the protein content in mushrooms increased about 3-fold (Han, 1989), and the synthesis of some amino acids was stimulated in the cultured mushroom (Hao, 1991).

Table 3 shows the Se distribution in different components when the chemical extraction procedure was used as proposed by Piepponen et al. (1984). From 6.3 to $10.6 \%$ of the Se was found in low molecular weight compounds, $6.6-9.8 \%$ in the lipids and lipoproteins fraction, and $2.4-8.3 \%$ in the nucleic acids fractions with $53-71 \%$ remaining in the solid residue. According to the work of Piepponen et al. (1984), this solid residue contains mainly chitin, polysaccharides, and proteins. These results show that most of the Se was located in the chitin, proteins, and polysaccharides fraction.

Table 4 shows the results of Se distribution in different components using the extraction procedure proposed by Thanh and Shibasaki (1976). Less than $10 \%$ of the Se was found in low molecular weight compounds, and no Se was found in lipids. From 37.7 
Table 4. Percentage Distribution of Se in Soybean Components (\%)

\begin{tabular}{lllll}
\hline & \multicolumn{4}{c}{ content for given sampling site } \\
\cline { 2 - 5 } \multicolumn{1}{c}{ component } & $\begin{array}{c}\text { Enshi } \\
\text { county }\end{array}$ & $\begin{array}{c}\text { Beijing } \\
\text { city }\end{array}$ & $\begin{array}{c}\text { Tianshui } \\
\text { region }\end{array}$ & $\begin{array}{c}\text { Yanbian } \\
\text { region }\end{array}$ \\
\hline $\begin{array}{c}\text { low mol wt } \\
\text { compounds }\end{array}$ & $0.6 \pm 0.1$ & $6.2 \pm 0.5$ & $9.4 \pm 2.3$ & $9.0 \pm 1.1$ \\
$\begin{array}{l}\text { lipids } \\
\text { water soluble } \\
\text { proteins }\end{array}$ & $49.4 \pm 3.0$ & $53.5 \pm 1.6$ & $53.1 \pm 6.1$ & $37.7 \pm 1.8$ \\
$\begin{array}{c}\text { solid residuec } \\
\text { recovery (\%) }\end{array}$ & $38.6 \pm 1.0$ & $34.5 \pm 1.2$ & $33.1 \pm 4.5$ & $41.8 \pm 1.9$ \\
& 88.5 & 94 & 97.4 & 88.6
\end{tabular}

a Extraction procedure followed that proposed by Thanh et al. (1976); standard deviation was calculated from three duplicates $(\mathrm{N}=3) .{ }^{\mathrm{b}}$ Calculation based on the difference between the total Se determined before and after defatting; negative values or those within standard deviation were designated as ND. c This fraction was assumed to contain mainly nucleic acids, chitin, lipoproteins, and polysaccharides.

Table 5. Estimated Percentage Distribution of Se in Soybean Components by Combination of the Results from Two Extraction Procedures ${ }^{a}$

\begin{tabular}{lllll}
\hline & \multicolumn{4}{c}{ distribution for given sampling site } \\
\cline { 2 - 5 } \multicolumn{1}{c}{ component } & $\begin{array}{c}\text { Enshi } \\
\text { county }\end{array}$ & $\begin{array}{c}\text { Beijing } \\
\text { city }\end{array}$ & $\begin{array}{c}\text { Tianshui } \\
\text { region }\end{array}$ & $\begin{array}{c}\text { Yanbian } \\
\text { region }\end{array}$ \\
\hline $\begin{array}{c}\text { low mol wt } \\
\text { compounds }\end{array}$ & 3 & 5 & 10 & 9 \\
$\begin{array}{l}\text { lipids } \\
\text { nucleic acids }\end{array}$ & ND & ND & ND & ND \\
lipoproteins & 7 & 6 & 2 & 8 \\
$\begin{array}{c}\text { water soluble } \\
\text { proteins }\end{array}$ & 49 & 53 & 10 & 7 \\
$\begin{array}{c}\text { chitin and } \\
\text { polysaccharidesc }\end{array}$ & 29 & 20 & 21 & 38 \\
recovery (\%) & 91 & 93 & 96 & 89
\end{tabular}

a Data were calculated from those of Tables 3 and Table 4 , on the basis of the average or differences. ${ }^{b}$ Se in the fraction of lipids and lipoproteins in Table 3 was assumed to be only in lipoproteins. ${ }^{c}$ Assuming these three components are basically insoluble and the calculation was based on the difference between the solid residue in Table 4 and nucleic acids and lipoproteins in Table 3.

to $53.5 \%$ of the Se was found in water soluble proteins and $33.1-41.8 \%$ in the solid residue. The results with this procedure indicate that most of the Se is present in the water soluble proteins and solid residue fractions. No significant differences between the percentage distribution were found among samples of various Se concentrations.

Percentage distribution of Se in low molecular weight compounds shown in Tables 3 and 4 are in general comparable. With the exception of samples from E nshi county, these two independent procedures gave similar results. The defatting procedure used for Table 3 indicates $6-10 \%$ of the total Se is found in lipoproteins in soybean samples, but the other procedure shown in Table 4 indicates no Se with this fraction. Table 3 indicates that Se is bound to nucleic acids in the samples (2.4-8.3\%), using the procedure of Piepponen et al. (1984). Table 4 indicates that the solid residue con-

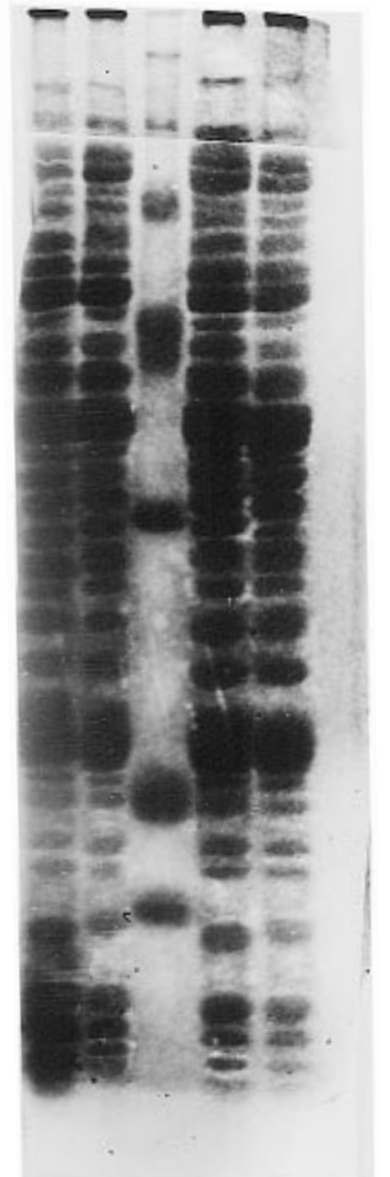

Figure 1. SDS-PAGE analysis of soybean samples using the procedure of Laemmli (1970). For sample preparation, $0.3 \mathrm{~g}$ of soybean powder was homogenized in $3 \mathrm{~mL}$ of a mixture of $62.5 \mathrm{mM}$ Tris $/ \mathrm{HCl}, 4 \%$ SDS, 5\% mercaptoethanol, $10 \%$ sucrose, and $0.002 \%$ bromophenol blue to obtain the test solution. The test solution was centrifuged at $5000 \mathrm{~g}$ and boiled for $3 \mathrm{~min}$ before use. Proteins in the test solution were concentrated in $5 \%$ acryl amide gel under a constant current of $10 \mu \mathrm{A}$ and electrophoresed in $12.5 \%$ gel for $30 \mathrm{~h}$ under a constant current of $20 \mu \mathrm{A}$. In a $200 \times 180 \times 3 \mathrm{~mm}$ cell for a total of 12 lanes, 6 lanes were added with blanks and others were added with test solution. At the end of the electrophoresis, the gel was stained with Coomassie Brilliant Blue R for $12 \mathrm{~h}$ (with $7 \%$ acetic acid and $30 \%$ methanol) and destained with $7 \%$ acetic acid for 3 days. The figure shows two sample bands (left), two sample bands (right), and the standard protein kit of different molecular weights for calibration.

tained $33-42 \%$ of total Se. About $7-10 \%$ of the Se was found in lipoproteins, and the rest was found in chitin and polysaccharides which contained the major amount of Se. The Se distribution in different components of soybean samples was estimated by combining the results from Tables 3 and 4 , as shown in Table 5 . The percentage of Se in chitin and polysaccharides was calculated from the difference between solid residue in Table 4 and nucleic acids and lipoproteins in Table 3. It should be noted that chemical extraction did not

Table 6. Se Distribution in Water Soluble Proteins ${ }^{a}$

\begin{tabular}{|c|c|c|c|c|c|c|c|c|c|}
\hline \multirow[b]{2}{*}{ sampling site } & \multicolumn{3}{|c|}{ in 115 fraction } & \multicolumn{3}{|c|}{ in 75 fraction } & \multicolumn{3}{|c|}{ in whey fraction } \\
\hline & Se content ${ }^{b}$ & $\%$ to total Se & $\mathrm{F}^{\mathrm{c}}$ & Se content ${ }^{b}$ & $\%$ to total Se & $\mathrm{F}^{\mathrm{c}}$ & Se content ${ }^{b}$ & $\%$ to total Se & $\mathrm{F}^{\mathrm{C}}$ \\
\hline Enshi county & $3790 \pm 169$ & 15 & 1.62 & $3381 \pm 368$ & 27 & 1.45 & $2748 \pm 68$ & 7 & 1.18 \\
\hline Beijing city & $443 \pm 24$ & 15 & 1.73 & $325 \pm 13$ & 22 & 1.27 & $718 \pm 8$ & 16 & 2.8 \\
\hline Tianshui region & $196 \pm 19$ & 17 & 1.96 & $133 \pm 15$ & 23 & 1.33 & $252 \pm 30$ & 14 & 2.52 \\
\hline Yanbian region & $171 \pm 6$ & 12 & 1.31 & $133 \pm 10$ & 18 & 1.02 & $184 \pm 6$ & 8 & 1.41 \\
\hline
\end{tabular}

a Extraction procedure followed that of Thanh and Shibasaki (1976), as subfractions of water soluble proteins in Table 4. b Data are expressed as milligrams of Se per killigrams of dried raw proteins. ${ }^{\mathrm{C}} \mathrm{F}=$ Se content in proteins/Se content in soybeans. 

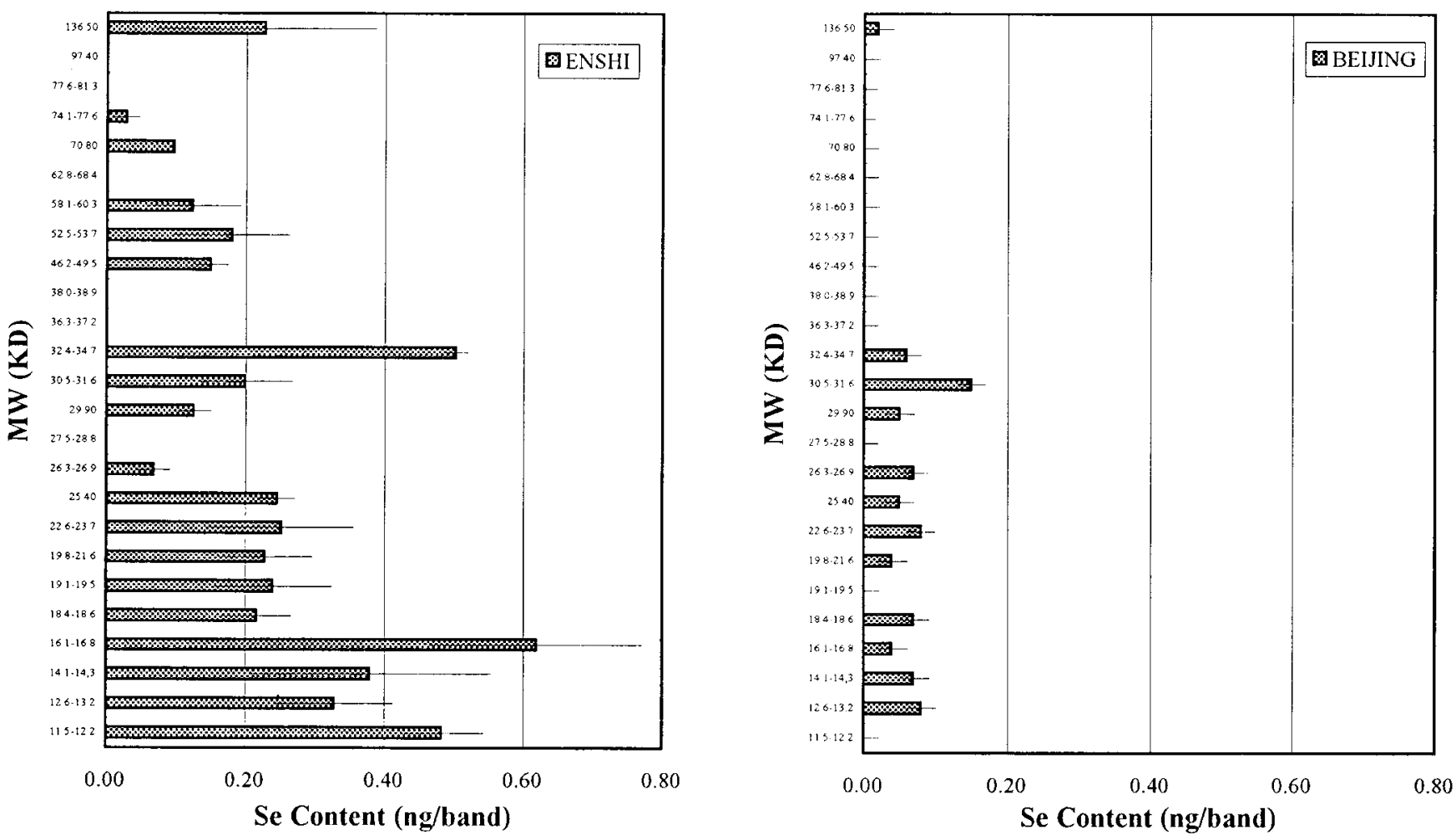

Figure 2. Sel enium distribution in soybean proteins from Enshi and Beijing. Bars indicate Se content, and lines indicate standard deviation for the visualized bands. The Se in bands in Ianes 1-6 was cal culated after the values for blanks were deducted (lanes 7-12). Only those bands whose averages exceed 2 standard deviations ( $N=3$ ) were taken as Se-containing bands.

result in compl ete isolation of various components, and, therefore, the result of the Se distribution in soybean components in Table 5 is a general estimation. Accordingly, Se was found mainly in water soluble proteins and chitin or polysaccharides of soybean. There is no significant relationship between the percentage distribution and the concentration of Se in the soybean samples. It appears that Se is incorporated into these components in proportion to the Se content.

From 82 to $84 \%$ of the Se could be extracted by a mixture of $\beta$-mercaptoethanol, $\mathrm{NaOH}$, and water with rice flour from Enshi county (Beilstein et al. (1991), and $84-85 \%$ of the Se was precipitated by $10 \%$ TCA. This paper indicates $60-70 \%$ of the Se was in proteins, mainly as selenomethionine (50-57\%). Results from other studies showed that $89 \%$ of ${ }^{75} \mathrm{Se}$ was with proteins in hydroponically grown soybeans (Mason, 1984; Sathe et al., 1992), and selenomethionine was one of the chemical forms in soybean with a normal Se content (Yasumoto, 1988). It was also found that most of the Se was found in proteins in garlic grown in Enshi county, with the distribution mainly in two acidic fractions of MW 30K and 33K (Wang et al., 1989). From 42 to $57 \%$ of the Se was in low molecular weight compounds, from $11-20 \%$ in lipids and lipoproteins, from 6 to $14 \%$ in nucleic acids, and from 16 to $21 \%$ in proteins, chitin, and polysaccharides when mushrooms were cultivated in high-Se soil or with ${ }^{75} \mathrm{Se}$ in the medium (Piepponen et al., 1984). Subsequent experiments found $65 \%$ of the total Se in protein and polysaccharides of cultivated mushroom, but those growing in media with added Se contained more Se than those growing in culture solution of normal Se level (Hao, 1991; Han, 1989). Two major molecular weight fractions of MW 575.8K and 18.8K of Se-containing polysaccharides have been purified from high-Se garlic (Wang et al., 1989). Se has been reported to bind to the 4 and 6 positions of the synthesized $\mathrm{Se} \kappa$-carrageenin and $\mathrm{Se}$ chondroitin sulfate (Tang and Rui, 1988; Peng and Peng, 1993). Se-containing tRNA has been found in wheat seedling cultivated in ${ }^{75}$ Se medium (Huang and $\mathrm{Xu}$, 1994), suggesting that Se is incorporated into proteins, polysaccharides, and nucleic acids in plants. Se in water soluble proteins and lipoproteins (Table 3) accounted for $46-59 \%$ of total Se in the samples. The low molecular weight compounds probably also contain Se-peptides. The sum of both procedures for soybeans is close to previous research for rice and corn grown in Enshi county (Beilstein et al., 1991).

The water soluble proteins were further separated into three fractions (11S, 7S, and whey proteins) according to the method of Thanh and Shibasaki (1976). Most of the water soluble Se was in the 7S fraction (Table 6), which is consistent with previous research (Yasumoto et al., 1988; Sathe et al., 1992). The Se content on the protein basis ( $F$ calculation) in these three protein fractions varied with the Se level in the samples. In high-Se samples, the greatest amount of Se was with the 11S fraction followed by a different order with the other samples which were whey $>115$ $>$ 7S. The absolute amounts of Se in 11S, 7S, and whey were $0.44,0.33$, and $0.72 \mu \mathrm{g} / \mathrm{g}$ of protein, respectively, with a total recovery of $53 \%$. The results for Seadequate samples (Beijing city) are similar to the data of Sathe et al. (1992) and Yasumoto et al. (1988), who found the absolute amounts of Se in 11S, 7S, and whey were $0.35,0.36$, and 0.58 , respectively, with a total recovery of $59.6 \%$. For both Se-deficient and high-Se samples, the results are different from previous data; more Se was found in 7S or 115 than in the whey protein fraction of high-Se samples, but the reverse is true for the low-Se sample. As indicated in Table 6, accumulation of Se in the 115 fraction is $1.3-2$, in 75 is $1.0-1.4$, and in whey is $1.2-2.8$. It should be noted that the calculation of the ratio between $11 \mathrm{~S}$ and $7 \mathrm{~S}$ is relatively constant (11S:7S $=1.12: 1.47)$. 
Two samples from the seleniferous area (Enshi) and from adequate region (Beijing) were selected for SDSPAGE separation of proteins. The bands were assumed to be Se-containing ones in which the averages exceeded two standard deviations $(\mathrm{N}=3)$ after the corresponding blanks were subtracted. The stained gel and determination results are shown in Figures 1 and 2 .

A total of 27 proteins or their subunits bands could be found on the gels. Among them, 19 bands were estimated to contain Se of the sample from Enshi county, while only 12 contained Se from the sample of Beijing (Figure 2). The band location and molecular weight distribution of Se proteins were compared with those obtained by Sathe et al. (1992), who used a ${ }^{75} \mathrm{Se}$ labeling experiment and reported 13 bands of ${ }^{75} \mathrm{Se}$ radioactivity. From comparison of this work with previous data (Sathe et al., 1992), bands of 77.6-81.3K, 74.1-77.6K, and 46.2-49.5K, belong to 7S globulin ( $\beta$ conglycinin) polypeptides $\alpha^{\prime}, \alpha$, and $\beta$, respectively, and only polypeptides $\alpha$ and $\beta$ contain Se in the sel eniferous sample. For the Se-adequate sample (Beijing), 7S globulin contained no Se. The results are different from those reported by Sathe et al. (1992), in which a total of $9.2 \%$ of ${ }^{75} \mathrm{Se}$ radioactivity was recovered from $7 \mathrm{~S}$ globulin with distribution in all three subunits. The difference was because 7S globulin contains relatively small amounts of Se (for example only $0.4 \%$ of Se in polypeptides $\alpha$ was found in the total Se recovered from gel in this work). Thus, Se in polypeptides $\alpha^{\prime}$ could be easily overlooked in the calculations. It should be noted also that intrinsically label ed ${ }^{75} \mathrm{Se}$ was used in the work of Sathe et al. (1992), but the samples in the present study were grown in natural environments.

The band of MW 32.4-34.7K is the acidic subunit of $11 S$ (A3). The band of MW 30.5-31.6K includes polypeptides of 7S (A1a, A2, A1b, and A4) and contains Se in both samples. The Se-band of MW 136.5K represents an unknown subunit of whey and contains Se in both samples. The bands of MW 29.9K, 26.3-26.9K, 25.4K, 22.6-23.7K, and 19.8-21.6K were unidentified as soy peptides, such as subunits of whey protein, $2 \mathrm{~S}$ protein, or lectin peptides. They contain Se in both samples. Four bands in the molecular range of 14.1-19.5K were combined in one peak in previous work (Sathe et al., 1992) and separated in the present work. Among them, the band of 19.1-19.5K bel onged to the whey fraction and the sample from Beijing did not contain Se. The band of 18.4-18.6K includes polypeptides of $11 \mathrm{~S}$ (B3, B1a, B2, B1b, and B4) and contains Se in both samples. The band of 12.6-13.2K belongs to the acidic subunit of $11 \mathrm{~S}$ (A5) and contains Se in both samples. The bands of $11.5-12.2 \mathrm{~K}$ belongs to small molecular peptides.

Since the same sampling vol ume was used for SDSPAGE separation, the results show that the Se content in most of Se-bands is variable with the Se concentrations in the samples, with the exception of the band of MW 26.3-26.9K. This indicates that Se incorporated into protein fractions is dosage dependent and, thus, is mostly nonspecific. Most of Se was found in whey proteins and only 16.2 and $24.8 \%$ in $11 S$ polypeptides for samples from Enshi and Beijing, respectively. This is different from that reported by Sathe et al. $(47.22 \%$ in 11S). It is concluded that affinities of whey protein and, to a lesser extent, the affinity of the 11S globulin polypeptides bind Se stronger than that of 75 globulin polypeptides. The binding of 75 and 115 under an excessive Se environment appears to be mostly nonspecific, and easily detached from proteins during SDS-
PAGE separation. Different results reported by various authors could also be due to the chemical form of Se used, which has been reported to influence the disposition of this element (Xia et al., 1993).

\section{CONCLUSIONS}

Selenium in soybeans is mainly in proteins, chitin, and polysaccharides. Affinities of whey protein and the 115 globulin polypeptides are stronger for Se than that of 75 globulin polypeptides. The disposition of Sein 7S and 11S under excessive Se environment is mostly nonspecific and can be easily removed from proteins during SDS-PAGE separation.

\section{ACKNOWLEDGMENT}

We thank Ms. Sun J infeng and Miss Song Weiping for excellent technical assistance. We also thank Prof. P. D. Whanger of Oregon State University for revising the manuscript.

\section{LITERATURE CITED}

Beilstein, M. A.; Whanger, P. D. Chemical forms of selenium in rat tissue after administration of selenite or selenomethionine. J . Nutr. 1986, 116, 1711-1719.

Beilstein, M. A.; Whanger, P. D.; Yang, G. Q. Chemical forms of selenium in corn and rice grown in a high selenium area of China. Biomed. Environ. Sci. 1991, 4, 392-398

Cui, J. P., Yin Z. H. Influences of applying Se to soil on chemical speciation of Se and quality of crop's seed. Acta Appl. Ecol. (China) 1993, 4, 303-307.

EGAS. Geographical distribution of selenium content in the topsoil in China and its association with selenium-responsive diseases in human and animal. Geogr. Res. (China) 1990, 3, 47-49.

Gu, G. W.; Selenium and cancerous epidemiology. Int. Med. (China) 1989, No. 5, 176-177.

$\mathrm{H}$ an, M. Se-containing components in Se-rich mushroom, M.S. Dissertation, Beijing Medical University, Beijing, China, 1989.

Hao, L. S. Se-rich mushroom and its Se-containing components. M.S. Dissertation, Beijing Medical University, Beijing, China, 1991.

Hou, S. F. Retention and effects of supplemented Se compounds to human in low-Se area. Acta Sci. Circumstantiae 1989, 9, 49-54.

Huang, K. X.; Xu, H. B. Separation, characterization and biological activity of SetRNA in plants. Presented at the Frontier Symposium on Bioinorganic Chemistry, Taiyuan, China, J uly 15, 1994; B3.2.

Laemmli, U. K. Cleavage of structural proteins during the assembly of the head of bacteriophage T4. Nature 1970, 227, 680-685.

Mason A. C. Ph.D. Dissertation, Purdue University, W. Lafayette, IN, 1984.

Mao, D. J .; Shu, H. S.; Yang, H. Y.; Wang, Y. J .; Yu, X. T. Epidemic survey of Se intoxication in Exi autonomic region, China. Chin. J . Endemiol. 1990, 9, 311-314.

Peng, B.; Peng, A. Selenochondroitin sulfate and a comparison of its toxicity with that of sodium selenite. J. Xiangtan College (China) 1993, 14, 24-29.

Peng, A., Wang, Z. J., Wang, W. H.; Yang, C. L. A new hypothesis for the etiology of Kashin-Beck disease. J. Environ. Sci. (China) 1991, 3, 5-14.

Piepponen, S.; Pellinen, M.J .; Hattula, T. The selenium of mushroom. In Trace Element Analytical Chemistry in Medicine and Biology; Peter, B., Peter, S., Eds.; de Gruyter: Berlin, 1984; pp 159-166.

Sathe, S. K.; Mason, A. C.; Rodibaygh, R.; Weaver, M.; Chemical form of selenium in soybean (Glycine max L.) lectin. J . Agri. Food Chem. 1992, 40, 2084-2091. 
Tang, J . J .; Rui, H. F. Preparation, physicochemical properties and biological activity of seleno-kappa carrageen. Acta Biochem. Biophys. (China) 1988, 20, 259-262.

Thanh, V. H., Shibasaki, K.; Major proteins of soybean seeds. A straightforward fraction and their characterization $\mathrm{J}$. Agric. Food Chem. 1976, 24, 1117-1121.

Wang, Z. J. Some biogeochemical aspects of selenium in Chinese low-selenium belt. Environ. Chem. (China) 1993, 12, 237-243.

Wang, Z. J .; Sun, J . F. Selenium determination at ppt level using a HPLC-FLD System. Acta Sci. CircumstantiaeSinica 1988, 8, 121-124.

Wang, W. Z.; Tang, J . J .; Peng, A. The isolation, identification and bioactivities of Seproteins in the selenium rich garlic. Chin. Biochem. J . 1989, 3, 229-234.

Wang, Q. G.; Xie, G. G.; Huang, Y. C. The determination of some elements in mussel (C86-701) by X-ray fluorescence spectroscopy. Spectrosc. Spectral Anal. 1991a, 11, 45-48.

Wang, Z. J .; Xu, L. Q.; Li, H.; Peng, B.; Rui, H. F.; Wang, W. $\mathrm{H}$.; Peng $\mathrm{A}$. Role of interaction between selenium and organic matter on cause of Kashin-Beck disease. J . Environ. Sci. (China), 1991b, 3, 15-28.
Xia, Y. M.; Zhao X. H.; Zhou Y.; Zhu, L. Z.; Whanger, P. D. Effects of Se on Se containing components of human blood. Acta Nutr. Sin. 1993, 15, 157-162.

Yang, B. W. Distribution and characteristics of seleniferous regions in china. Chin. J . Endemiol. 1993, 12, 27-31.

Yasumoto, K.; Suzuki, T.; Yoshida, M. Identification of selenomethionine in soybean protein. J. Agric. Food Chem. 1988, 36, 463-467.

Yin S. P.; Gu, L. Z.; Zhou, R. H. Content of Se and other elements in commercial food items in Beijing. Acta Nutr. Sin. 1986, 8, 27-29.

Received for review March 7, 1995. Revised manuscript received J uly 28, 1995. Accepted May 28, 1996. ${ }^{\otimes}$ This work was supported by Chinese National Science Foundation.

J F950133H

${ }^{\otimes}$ Abstract published in Advance ACS Abstracts, J uly 15, 1996. 